\title{
REINVENTANDO A CIDADE - MULHERES, ANTROPÓLOGOS E A TEMPORALIDADE NA CIDADE CONTEMPORÂNEA
}

\author{
Micheline Ramos de Oliveira \\ Doutoranda PPGAS/UFSC \\ Ana Luiza Carvalho da Rocha (orientação)
}

A cidade considerada como "objeto temporal" (Rocha \& Eckert, 2005) é o que viabiliza a escritura desse artigo que tem como objetivo último a apropriação de narrativas biográficas (Ricoeur, 2007) de mulheres citadinas que trazem em suas trajetórias nítidos itinerários urbanos demarcadores de um "viver a cidade" constituído de "um tempo coletivo que as ultrapassa", mas que porém, como poderemos observar nas narrativas de Fênix e Domitila uma durée social que "lhes confere um lugar determinado na forma como suas decisões alocam-se num espaço determinado"(Rocha \& Eckert, 2005), seja esse espaço representado aqui, por exemplo, por Salvador e São Paulo no caso de Fênix ou Campo Grande e Rio de Janeiro se nos debruçarmos no itinerário de Domitila.

Ainda, a eleição de uma escrita voltada para a problematização do "tempo e a cidade" numa tese sobre mulheres e violências deve alertar que para além e no entremeio de um suposto caos formatado por vivências conflituosas e de violências existe "a cidade e seus territórios como fruto de uma consolidação temporal vivida na errância das formas de vida social dos grupos urbanos que a ela pertencem, configuradas e reconfiguradas" (Rocha e Eckert, 2005: 96), nesse caso, pelas narrativas biográficas de Fênix e Domitila, que fornecem, a meu ver, elementos bastante elucidativos no que diz respeito a relevância de se focalizar "na" e "a" cidade os estudos de violências no Brasil contemporâneo.

Aqui antes de fazer a defesa de um estudo inóspito da cidade, pela cidade, estáse compartilhando das reflexões citadinas que perpassam estudiosos desde a Escola de Chicago, como Simmel, Park, Wirth, etc, fenomenólogos, como Schutz e o tupiniquim Gilbero Velho, até as pesquisadoras brasileiras sulistas Eckert e Rocha, que conduzem seus estudos na cidade por uma ótica hermeneuta, que por sua complexidade (Morin, 1999), abarca o "pensamento da diferença". Segundo as autoras: "Essa intenção 
metodológica que aborda o fenômeno urbano a partir de uma razão hermenêutica remete ao enfoque da "unidade estilística" da cidade como objeto temporal, fora de um círculo vicioso" (Rocha \& Eckert, 2005:95).

Assim, ainda com as autoras, nesse estudo, o foco concentra-se no "conhecimento compreensivo da cidade segundo os acontecimentos anódinos que ocorrem no seu interior e a efervescência que rege a vida ordinária de seus habitantes" (Rocha \& Eckert, 2005: 95), como poderemos averiguar nos densos, extensos, mas creio necessários relatos de nossas protagonistas que serão apresentados ainda nesse capítulo mais adiante.

Preliminarmente, antes da apresentação das narrativas de nossas interlocutoras, creio que seja oportuno fazer uma reflexão sobre o trabalho do antropólogo na cidade, algo que penso deva ser revisitado cada vez que uma pesquisa antropológica aponte para uma etnografia da e na vida citadina, já que mais do que meras repetições os incessantes movimentos de ser e estar na cidade, de constituí-la e ser constituído por ela podem ser revigorados por nossa matriz disciplinar (Cardoso de Oliveira,1997) a cada novo elemento etnográfico aí apreendidos, a cada novo olhar atento a infinidade de elementos e ângulos incessantemente construídos e reconstruídos nessa "paisagem" (Simmel,2002) "polifônica” (Canevacci, 1997), que não podemos jamais esquecer, para além de nossos interlocutores, também habitamos e somos habitados por ela. Nesse ínterim invoco as sábias e contundentes palavras do último autor:

A cidade é um contexto bem poderoso e "falante", que não se deixa reduzir a um simples pano de fundo, a uma cidade-panorama sobre a qual o antropólogo possa estender seu olhar lúcido e penetrante: mas esse contexto (...) encerra, modela e "veste" o pesquisador enquanto exercita seu poder criador...(Canevacci, 1997:80).

Ora, se "o antropólogo é (...) possuído não só pela sociedade abstrata, mas também, e sobretudo pela cidade que ele possui (...) e a cidade está nele" (Canevacci, 1997:81), parece-me óbvio, como o foi direta ou indiretamente para um Simmel, um Lévi-Strauss, ou um Benjamin apreender de forma analítica o incômodo, mas talvez necessário alerta citadino, que no confronto com nossa memória (Bachelard,1988) nos faz lembrar a cada "diferença” (Eckert \& Rocha, 2005) étnica, social, econômica, religiosa, política, entre outras etnografadas na cidade, o lugar que habitamos nela, e junto com ele todos os "fantasmas" vinculados a nossas escolhas ético e políticas, 
travestidas nesse caso, por nossas escolhas teórico-metodológicas que indubitavelmente nos conduzem em campo.

Nesse sentido, não nos faltam exemplares de pesquisas, das clássicas as mais atuais, que nos permitem observar numa leitura mais atenta e refinada o "imaginário" de cidade dessas antropólogas e antropólogos como parte constitutiva de suas etnografias na e da cidade, a saber: as densas narrativas etnográficas sobre "uma cultura do medo" em Porto Alegre das antropólogas também moradoras da mesma cidade (Eckert \& Rocha, 2005) ; ou uma Rio de Janeiro "violenta", descrita obsecadamente por meio de um mapeamento das favelas cariocas por (Zaluar,1985,1993,2003) e seguidores, ou ainda uma sociedade média carioca em conflito descrita pelo também carioca (Velho,1981,1994,2000); ou o relato desolado e iluminista do europeu estruturalista (Lévi-Strauss, 2004) em sua descrição sobre São Paulo; ou uma São Paulo contemporânea desnuda sob a tutela do italiano especialista em comunicação (Canevacci,1997) ou ainda uma São Paulo "de muros" tão bem elucidada por (Caldeira, 2000) e assim por diante.

Respeitando as peculiaridades de cada uma dessas etnografias citadinas, vale dizer que penso nelas menos como originalidade de seus etnógrafos e mais como uma “coleção”(Benjamin, 1969) emblemática de uma época, de um autor, e enfim de seus pressupostos, aqui decididamente ligados a uma idéia de etnografia que "estuda, ao mesmo tempo em que é parte da invenção e da interrupção de totalidades significativas em trabalhos de importação-exportação cultural" (Clifford, 2002:169).

Assim, creio que seja interessante pensarmos na idéia de collage como propulsora do exercício etnográfico realizado por esses pesquisadores, já que fundamentalmente aqui esse recurso estilístico, e creio em outras pesquisas de antropologia urbana, pode ser apreendido.

Ora, só o fato do etnógrafo enquadrar e escolher narrar uma cidade focalizando determinados fenômenos (violência, medo, segurança, cidadania, conflito, etc) traz a exposição "os cortes e suturas do processo de pesquisa", desvelando ao contrário de uma ciência preocupada em dissipar incongruências (Clifford, 2002) o caráter construtivista da etnografia, a medida em que a etnografia, pensada como um mecanismo de collage produz "momentos nos quais distintas realidades culturais são retiradas de seus contextos e submetidas a uma perturbadora proximidade"(Clifford, 2002). 
Assim, penso que a escolha daqueles pesquisadores por enfatizar alguns ângulos da cidade narrada em detrimento de outros está intrinsecamente relacionada a um projeto de disciplina, a medida que o mecanismo de collage ali presente, além de não ignorar "aqueles elementos da outra cultura que transformam a própria cultura do investigador distintamente incompreensível"(Clifford, 2002), prestam contas mais uma vez ao caráter "construtivista da etnografia", no que jaz, mesmo que de forma não consciente, a exposição da "conjunção de juízos estéticos e reflexivos nas adoções metodológicas" (Eckert \& Rocha, 2000) do etnógrafo por meio de sua narrativa seletiva.

Parece-me que as etnografias aqui citadas sem exceção revelam a estética do etnógrafo que tenta revelar ao mundo através de sua obra de etnografia a necessidade de ampliação das fronteiras do humano, aqui, leia-se que o exercício de ampliação, antes do que reconhecer o exótico no outro, está atrelado a idéia de defesa de "um pleno potencial humano de expressão cultural", lugar em que o homem, incluindo aí o próprio etnógrafo, não poderia mais ser pensado sem os seus “outros”, seus "duplos".

No mais, visualizo nessa reflexão um elemento importante para o desnudamento do "processo pelo qual o etnógrafo transmuta os dados sensíveis e opacos da realidade social em representações e formas simbólicas, transformando os acontecimentos exteriores vividos por um agrupamento humano em verdadeiras narrativas"(Rocha, 1995: 91). Enfim percebo esse conjunto de etnografias sobre e na cidade antes que dados brutos de uma realidade dada, como uma narração, como rastros de uma "feição fabulatória do discurso antropológico".

E é ao aderir à idéia do discurso antropológico considerando sua "feição fabulatória" (Rocha, 1995) que compactuo com a concepção de "estrutura" vinculada a uma dinâmica transformadora que pode nos permitir aprofundar nossa discussão em torno da idéia da memória vinculada aos estudos da e na cidade, pertencente ao domínio do fantástico (Eckert \& Rocha, 2000), capaz de "modificar o próprio campo imaginário" (Durand, 2002: 63), nesse caso, como veremos adiante, pressuposto fundamental para entendermos como as trajetórias das mulheres que serão aqui expostas demonstram o agenciamento de suas vivências de violências indubitavelmente

\footnotetext{
${ }^{1}$ Mais uma vez com Clifford (2002) parece-me interessante lembrar que "A verdade etnográfica, para Mauss, era incansavelmente subversiva em relação às realidades superficiais. Sua principal tarefa era descobrir, em sua famosa frase, as várias "lunes mortes", pálidas luas, no 'firmamento da razão". Nesse sentido, "não há melhor sumário da tarefa do surrealismo etnográfico, uma vez que a "razão" referida não é paroquial racionalidade ocidental, mas o pleno potencial humano de expressão cultural”(pp.146).
} 
vinculadas a determinada forma de imaginação e " do conjunto das estruturas e dos regimes que ela subsume"(Durand, 2002: 64) acerca das cidades narradas.

Dessa forma, concorda-se com um método antropológico que traga em seus fundamentos à indispensabilidade dos estudos de memória que contemple o espaço fantástico como a forma de uma imaginação criadora constituinte não só das narrativas acerca das cidades dos informantes, mas do discurso do próprio antropólogo sobre essas, como bem já o disseram (Eckert \& Rocha, 2005).

Nesse ensejo Simmel (1998) poderá nos fornecer uma ferramenta importante para pensarmos e refletirmos sobre o processo de nossas pesquisas na cidade a medida em que demonstra o sentido e validade da ênfase na forma e no procedimento diante da constatação de que o processo afeta os resultados. Isso quer dizer que o conteúdo só terá sentido enquanto relacionado a uma forma (Waizbort , 2000).

Poderíamos pensar então que o aspecto formal do procedimento coordena, determina o processo de investigação, assim, dando ênfase aos processos, temos a possibilidade de ver como, por de trás de um conteúdo fixado há um processo que conduziu a ele (Waizbort, 2000). Se esse processo se dará de uma forma ou de outra dependendo por exemplo de nossas escolhas teórico-metodológicas, das suas formas de lidar e proceder com o objeto, (Simmel, 1998) brinda-nos com a possibilidade da mobilidade perante esse processo, eis o desafio: pensarmos, nesse caso, nossos estudos de violências na cidade não mais pautados por uma tradição, embora camuflada, ainda inspirada por uma sociologia durkheimiana do consenso e das sociologias marxistas e weberianas do conflito.

Aqui permitam-me uma digressão: Se existe a possibilidade de ruptura, do modo como estudamos as violências no Brasil, porque insistimos em pressupostos teóricos, nesse caso, muitas vezes pautados por uma teoria do consenso, que nega o conflito, ou por uma teoria que o abomina, ao invés de vê-lo como constituinte de um processo de interação? Aqui, recorro a (Deleuze e Guattari, 2004) quando esses discorrem sobre o "princípio de ruptura" do rizoma. Para os autores

...um rizoma pode ser rompido, quebrado em um lugar qualquer, e também retoma segundo uma ou outra de suas linhas e segundo outras linhas...Todo rizoma compreende linhas de segmentaridade segundo as quais ele é estratificado, territorializado, organizado, significado, atibuído, etc.; mas compreende também linhas de desterritorialização pelas quais ele foge sem parar. Há ruptura no rizoma cada vez que linhas segmentares explodem numa linha de fuga, mas a linha de fuga faz parte do rizoma. Estas linhas não param de se remeter uma às outras. È por isto que não se pode contar com um dualismo ou uma dicotomia, nem mesmo sob a 
forma rudimentar do bom e do mau. Faz-se uma ruptura, traça-se uma linha de fuga, mas corre-se sempre o risco de reencontar nela organizações que reestratificam o conjunto, formações que dão novamente o poder a um significante, atribuições que reconstituem um sujeito - tudo o que se quiser, desde as ressurgências edipianas até as concreções fascistas. Os grupos e os indivíduos contêm microfascismo sempre à espera de cristalização...O bom e o mau são somente o produto de uma seleção ativa e temporária a ser recomeçada... (Deleuze e Guattari 2004: 18).

Enfim, é imbuída por essas reflexões precedentes que lhes apresento Domitila e Fênix respectivamente e suas emblemáticas narrativas por mim editadas marcadas por seus movimentos por cidades brasileiras, nas quais questões étnicas, éticas, morais, sociais, religiosas, etc, constituem o organograma de suas trajetórias nitidamente demarcadas pelo "lugar" que lhes acontece/aconteceu viver.

\section{DOMITILA...}

Qu sou de Qsião Daulo, saí com sete anos de lá. Ohinha mãe tinha os relacionamentos, ai ela se envolveu com uma pessoa que se diz ser meu pai...sou fruto de um amor proibido,...como meu pai sabia que minha mãe gostava de festa, de sair, da noite, ele queria me tomar dela, ele queria que eu fosse criada por ele, não por ela... relacionamento deles foi só aquelas relaçốes de noite...eu nem cheguei a conhecer meu pai... a minha mäe tämbém sôfreu muito...os pais dela, os meus avós eram muito duros... \& $u$ vendo as cabeçadas que ela deu...eu resolvi não fazer igual... A Rinha mãe tinha uma amiga de Ssergipe que ela conheceu em Ssão Daulo e eu sempre ia pra casa da mäe dessa amiga da minha mãe, essa amiga da minha mãe tinha uma irmã que tinha a mesma idade que eu sete anos, essa familia tinha saido de Ssergipe a procura de emprego em OSão Daulo... Todo final de semana quando näo ficava no internato, ficava là porque minha mãe trabalhava de doméstica... Pomo o nosso relacionamento não era bom, quando chegava o final de semana eu näo queria ficar com ela, eu queria ficar no internato, dai ela ficava brava comigo...como uma fitha não queria ir com uma mãe???.. S Sessa época teve uma enchente em Osão Daulo, então a fámilia da amiga da minha mäe que era de Ssergipe voltou pra lä, a minha mãe me mandou com essa familia pra I Ssergipe com o intuito de me buscar em quinze dias.. Ora hora eu adorei, porque eu tinha uma convivência muito boa com aquela familia... E $n$ ntão fui pra Osergipe... Todo mundo perguntava: e a mãe dela? Dassou quinze dias, passou um mès, passou dois meses, quatro meses, uma ano, dois anos...e nada da minha mäe...nenhum sinal dela... Xesssa época eu voltei a estudar..já havia comesado no internato... estudei desde pequena...aprendi muita coisa em Qsergipe a a cultura é bem diferente...é tudo bonito... a diversidade da comida...eu tenho o maior orgulho de ter ido pra lá... foram bons anos da minha vida... Enquanto isso meus pais estavam na maior briga lá em Qsão Daulo... \&u tava na boa lá $\mathrm{cm}$ Qsergipe... \& u vendia manga na feira de artesanato... andei em pau de arara... foi um momento mágico na minha vida... Depois de um tempo a familia sergipana conseguiu encontrar minha mãe que havia sumido de nossas vidas,

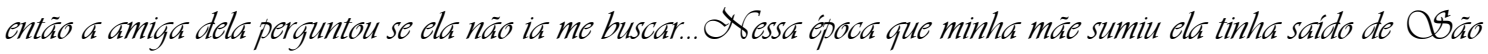
Daulo corrida do meu pai e ido pra Pampo Grande... Xesssa época eu já tinha me apegado muito á áquela 
familia... lá ia eu viajar de novo? Chas tive que voltar pra junto de minha mãe, então fui morar com ela em $P$ ampo Grande. Ali eu já tinha 15 anos... A minha mäe naquela época era uma estranha pra mim... Quando eu era pequena minha mãe não tinha paciència comigo, batia muito em mim...por isso eu preferia ficar no orfanato do que ir com ela... ela só me judiava... ela saía a noite no final de semana e me deizava sozinha... Chuitas vezes ela me deizava na casa da patroa dela...me trancava no quarto de empregada e dizia pra eu não sair...nä́ fazer barulho... Deizava uma garrafinha com água e saía... Quando voltei a morar com ela em Pampo OGrande, eu só pensava que ela ia me judiar novamente como ela fazia quando eu era pequena... \&u não gostei de cara de Pampo Grande porque não tinha praia e a terra era vermelha... Quando eu cheguei lá a minha mäe ainda era da vida da noite... de bebida...bar... muita cenveja... () meu tormento foi muito grande...fiquei revoltada com aquilo...e tinha quinze anos e ela só me batendo... o meu avồ tinha chicote de bater em cavalo, dai ela me batia com aquilo...com tudo que ela encontrava na frente ela me batia... \& $m$ funçäo disso eu näo queria mais morar na cassa da minha avó, eu queria morar na casa da minha tia, irmä da minha mäe, porque elas tinham uma outra maneira de viver... final de semana eu pedia pra minhas primas pedirem pra minha mãe pra eu ir pra casa delas eu morria de medo da minha mãe... Chinha mäe nessa época tinha vários namorados...e eu odiava... minha mäe namorava caminhoneiro... bèbado de bar... ela levava essa gente pra dentro de casa... Xessa época minha mäe me colocou a trabathar junto com ela, ela era doméstica e eu comecei a trabalhar como babá... Tinharm duas casas uma na frente da outra, da minha tia irmã da minha mãe e da minha avó... minha mäe morava com as duas ao mesmo tempo...dependendo da noite quando ela chegava da rua, a casa que tivesse aberta ela entrava... minha mäe chegava bêbada em cassa.. Xessa época eu comecei a estudar a noite...era dificil... \&u chegava do colégio e encontrava ela sempre com um cara diferente, cada dia um cara diferente.. quando ela saía de perto, ela pedia pra eu fazer companhia pra esses homens e eles já me cantavam... foram acontecendo essas coisas...eles mexiam comigo...me bulinavam... Xessa época também o meu primo comecou a contar uma história pra mim da minha mäe... a minha tia que eu gostava muito, que eu sentia que ela me acolhia ela não se dava bem com minha mãe... guando a tia tinha ganhado bebe...tava de resguardo e a minha mĩe foi cuidar dela a minha tia pegou a minha mẽe tendo relação sexual com meu tio no quarto do casal... enquanto minha tia tava descansando na varandinha os dois estavam transando no quarto... imagina minha tia tinha acabado de ter bebê...cesariana . tava toda furada e presenciou uma cena dessas... a minha tia arrebentou todos os pontos dela... bateu nos dois... Sesse tempo que eu tava em Pampo Grande minha mäe tava se relacionando sexualmente com o próprio sobrinho... dai que eu fui entender porque minha mãe dormia na casa da minha avó e da minha tia...meu primo de primeiro grau... Dai eu comecei a me questionar o por que disso... dai comecei a perguntar sobre o passado da minha mĩe com as minhas primas, dai descobri porque minha mãe tinha ido embora para Osantos, foi porque minha mũe tinha ficado gránida e foi expulsa de casa pelo meu avô, chegando lá ela deu meu irmão para outra pessoa criar... outro fruto de um amor proibido...esse morreu e um outro irmão que eu tenho é traficante...é foda...A partir dai foram brigas contínuas, muitas discussöes...e eu fui espancada por ela várias vezes... a aqueles homens que ela levava pra dentro de casa continuavam me atormentando... fallava pra ela por que tu não para de beber...eu falava pra ela que eu era filha única e ela devia cuidar de mim, dai ela dizia que eu era muito espertinha...nunca chamei ela de mäe chamava ela de

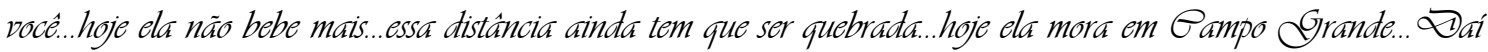
eu comecei a estudar, estudar..já ia de manhã pro senvico com o material escolar, sáa de lá pegava ônibus e ia pra escola... Ohegou uma época que eu cansei de trabalhar e estudar...era muito dificil eu não tinha apoio de ninguém... Foi muito triste... \& $u$ não gostava de homem por causa das coisas que a minha mãe fazia... eu tinha nojo... Dra fugir daquela realidade a saida era viagem... Tinha uma vizinha nossa que trabalhava na caixa econômica e foi transferida para uma pequena cidade de Chato Grosso Osul, Qiviena, tem rio...uma delicia... dai eu fui com ela pra trabalhar de babá... Đai nessa época parei de estudar... comecei a pensar: pra que estudar, sei ler e escrever... Pomecei a colher essa frase pra mim...queria crescer mas näo tinha estudo, não tinha iniciativa, näo tinha

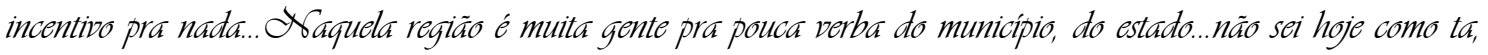
mas naquela época não tinha nada... Dai parei de estudar e comecei a trabalhar...não fazia curso, nãa fazia nada... Dai como nĩo acontecia nada naquela regiẽo, comecei a trabathar com as criancas, com o dinheiro que eu ganhava do trabalho de babá comecei a comprar medathas, doces, faria mapa do tesouro, faria equipes e montava 
gincanas com as crianças da vizinhança, da familia queria voltar a fazer isso hoje, só que fälta tempo... Dai essa minha patroa da caiza conseguiu um projeto pra eu desenvolver com as criancas ...como eu ficava triste quando via criancas que eram judiadas como eu fui, com esse projeto ajudei muitas familias.

Eá se ganhava muito pouco...como doméstica e babá a gente não ganhava quase náda... que ganhávamos nem chegava perto do salánio minimo... quando ganhei meu primeiro salánio eu comprei um shampoo... \& ra tanta pobreza, tanta miséria, que lá só tinha sabonete no banheiro, e quando tinha...sempre tinha vontade de comer isso, aquilo... fui no banheiro tomar banho, nunca esquego era shampoo de morango...comecei a ver aquela espuma branca.. fiquei encantada...demorei um monte no banho...o que aconteceu? Alpanhei um monte pelada no banheiro da minha mãe...eu gastei um pote de shampoo num dia só... senti uma sensagãa de poder... dai a minhaa vó bateu na porta e eu não saía. quando eu abri a porta. a minha avó abriu o banheiro... nessa hora eu cresci.. quando minha avó viu o pote de shampoo vazio no chão, ela fálou o que que é isso...quando eu comprei eu mostrei pra todo mundo... \& u fálei. o vó eu comprei com o meu dinheiro...pra que eu fui fálar assim com minha avó... minha mäe tava chegando do senvico... a minha mãe adorava me bater...me bateu nua...eu chorava...dai eu pensei em fugir...qualguer coisa eu chorava...eu ol thava aquelas marcas...porque fivela de cinto deizava marca...e chorava..

Teve um dia em que ela pegou o arreio do meu avô e comegou a me bater na cara... dai ela comegou a me enforcar. sorte que o meu tio tava em cassa, señ̃o ela tinha me matado...fazia tanto barulho aquilo no meu corpo...pra eu nãa berrar ela comegou a me enforcar...e cu comecei a engasgar... eu to vivenciando tudo isso enquanto to to contando...eu já superei tudo isso... mas ainda é muito doido lembrar isso... foi por um triz que ela nãa me estrangulou...chegou uma hora que trancou tudo... o meu tio chamou ela de louca...eu tinha vergonha...eu era vítima, mas sentia vergonha... \& $u$ apanhei muito e não morri.. o que eu passei eu não quero que ninguém passe... se depender de mim... Depois disso teve um nova tentativa...e foi a última...isso eu já tinha uns dezessete anos... ela levantou o bracgo eu segurei, levantou o outro braço mas eu nãa deixei e ela me othando... Até que ela desistiu acho que naquele momento tanto ela como eu percebemos que eu jä não era mais aquela menina, eu era uma mulher, e tinha tanta força ou mais do que ela, depois daguilo ela nunca mais tentou..é triste depois de tanto apanhar eu descobri que podia me defender, que não era tão fraca assim... foi só eu me defender que ela recuou... A minha mäe tinha um olhar muito feio, nunca mais vou esquecer aquele othar de ódio que ela estampava na cara quando tava sóbria... Algora ela ta regenerada.. A nossa relação sempre foi regada por muita violéncia.. A gente discutia muito, ela nunca fez o papel de mãe, ela era uma mulher da rua, da noite... Em bar de sinuca era só ela de mulher, o resto era tudo homem, e ela jogava pra caramba... ganhava... ela só tomava uísque, ou conhaque... minha mãe tinha até um time de futebol. Ás vezes ela sumia de casa, dai a gente ficava sabendo que ela dormia na casa dos homens, dos amigos cachaceiros... Até que um dia ela conheceu um cara no bar que bebia junto com ela... Xessa época ela só vinha na vó para pegar a roupa pra trabalhar e já saía... ela comegou a se envolver com esse cara... todo dia ele ligava pro trabatho dela...eu tinha um nojo...tinha um nojo de homem...por causa dela...por um lado foi bom esse relacionamento deles, porque um ajudou o outro a parar de beber.. hoje eles estäo de casamento marcado na igreja, casamento coletivo...comegaram a morar junto...eu tinha nojo das minhas roupas misturadas no mesmo cesto de roupa suja com as de um homem estranho...eu nãa gostava dele...comecaram a se envolver e ela comecou a sossegar o facho dela... Chas se antes eu jä não tinha lugar lá, naquele momento em que ela arrumou um homem eu nãuo tinha mais nada pra fazer lá... fo oi ai que eu recebi uma proposta para ser cozinheira no Qio de Ganeiro... Ofui trabalhar no Eeblon... Ali eu já tinha uns dezenove anos... Tem um pessoal carioca de classe média, médtia alta, que tem mania de pegar meninas do interior, tipo Pampo OGrande e explorar no sentigo doméstico... \& u só fazia comida, mas tinha uma menina de treze anos que tinha que limpar aquele apartamento imenso... \& era trabalho, tinhamos que senvir a mesa, levar a comida na bandeja e senvir os patröes... Essa gunia era novinha, mas era muito esperta... Eá eu também fazia compra no mercado, trazia notinhas... OCouve um momento em que os donos da casa comecaram a deixar dinheiro em todo canto da casa... A minha parte era só a cozinha, tanto que eu nem cheguei a conhecer todo o apartamento, só fui até a sala... () meu quarto e o da guria ficava no lado da área de senvigo, era muito maģa... tinha televisão... Essa menina pegou uma follha de cheque dos patröes e foi fazer compra... \& u mandei ela devolver e ela me mentiu que foi a patroa que tinha dado pra ela... \&u vi que o negócio näo ia prestar... eles eram racistas, eu era proibida de cruzar a porta da cozinha, 
só ia até a sala se tivesse que ajudar a senvir alguma refeicuão...e eu gostava, ficava no meu canto... um dia essa mulher sentiu falta do cheque... Che perguntou sobre ele e eu falei que eu nem entrava no apartamento, disse que não sabia de nada... E.sse dia foi horrivel...eu não queria entregar a guria..e a patroa ficou me pressionando perguntando onde tava a guria... Derguntavam pra guria, mas também olhavam pra mim...entraram no quarto pra olhar nossas coisas.. Até que eu falei pra eles que ela sabia onde o cheque tava... ela entregou o cheque e então o patrão pegou a havaiana dos pés dela e comecou a bater no rosto dela com a sandália e eu vendo tudo... a guria tinha treze anos e quando apanhou não deu nenhum pio, nãos saiu lágnima do otho dela náda... tava acostumada a apanhar...devia vim de uma vivéncia como a minha... foram olhar tinha um monte de coisa na bolsa dela arrumaram um vồo $e$ mandaram ela de volta pra casa, nesse dia ela me disse que eu seria a próxima porque os donos da casa não gostavam de negros... Pom o tempo eu comecei a conversar com o filho da patroa e ela proibiu dizendo que empregada não pode ficar conversando com filho de paträo... Ela tinha um sotaque de carioca bem forte, eu adoro sotaque de carioca, mas aquela mulher eu odtiava... $2 \mathrm{~lm}$ dia ela chegou em casa e o almogo ainda não tava totalmente pronto e ela foi bem grossa comigo dizendo que o almogo estava atrasado e que eu tinha que andar na linha, que eu escapei de nãu ir embora junto com a outra, que eu deveria ter contado logo de inicio que o cheque estava com ela e então fálou se eu tinha o mesmo costume da outra e fez um comentánio que pra mim foi a gota d'água, ela disse que essas negrinhas que vinham lá de Pampo Grande não eram confiáveis... Depois daquele dia eu nãa quis mais morar lä... Giquei naquela casa mais um mès e meio... Chas antes de ir embora fui conhecer o Q $Q$ io de Ganeiro, com o dinheiro que recebi fiz um monte de compra. Fomprei roupa, sapato, creme pro cabelo... Che levaram no aeroporto e voltei pra Pampo Grande... Phegando lá me chamaram de besta por ter ido com gente estranha pro QRio de janeiro e eu respondi que pelo menos eu conheci outros lugares... Eevei uma pasta pra alisar cabelo e comecei a passar no cabelo das meninas todas... Revei iogurte, bolachas, aquilo foi a festa pro pessoal da minha casa que näo tinha acesso a esse tipo de coisa... De volta a Pampo Grande a minha vida voltou a ser a mesma de sempre...eu jä não estudava mais... näo tinha mais nada pra fazer, comecei a ficar triste.. foi então que o marido da minha prima \& em Qtajai... Pomecou a trabathar em terraplenagem e alugou uma casa e chamou ela para vir... Quando ela disse que viria eu pedi pra ela me colocar na mochila dela, eu näo podia ver ninguém viajar que jä me animava para ir junto... Quando fez um ano que ela e o marido estavam morando aqui em Qtajai boa parte da familia veio para passar o natal e o ano novo, eu tentei vir também mais não consegui o dinheiro da passagem... Trabalhei um monte até nas eleiçäes na boca de urna pra dois partidos diferentes, em cada bairro eu vestia uma camiseta diferente, mas nũo teve jeito, nẫo consegui juntar o dinheiro todo, na época fältava em torno de uns trinta reais para completar a passagem de ônibus Pampo OGrande - Qtajai. Dassou algum tempo e minha prima teve bebê, quando saiu daqui ela jầ tinha uma menina e lá ganhou mais uma, aproveitando a situação eu escrevi uma carta pra ela que se ela quisesse eu vinha morar com eles em @tajai para ajudar a cuidar das crianças, ela me respondeu prontamente que estava com sorte porque o meu tio, pai dela tava vindo pra Stanta Patarina e poderia me trazer junto com ele, eu nem pestanejei, tudo que eu queria era fugir daquele inferno...um mès antes da partida eu já comecei a arrumar a minha mala. Quando eu cheguei aqui estranhei bastante, era muito diferente...era muito frio... as pessoas eram muito fechadas...eu näo fazia nada aqui além de cuidar das filhas da minha prima... Eu era a única negra da rua...todo mundo othava meio estranho pra mim... Chas foi indo, foi indo, mesmo as pessoas sendo bem resenvadas fui me acostumando... Até que as criancas foram pra creche e eu sem dinheiro comecei a procurar emprego... Até que eu consegui o emprego de senvicos gerias numa loja de cosméticos que produzia os próprios produtos... 叉ra mim foi aperdicãao, eu até hoje adoro cremes, shampoos, perfumes... quem trabalhava lá tinha o desconto de $50 \%$ na compra de qualquer produto, mas mesmo assim mesmo era caro, chegava no final do mès eu jâ tinha gastado boa parte do salário náquilo (risos)... Craquela época eu tava me achando o máximo, imagina ganhei um guarda-pó branco pra trabalhar, ganhava salánio de verdade, nunca tinha tido isso na vida...e ainda por cima fui promovida a assistente de produgãu, enchia frasco de perfume, etc.. ofoi um tempo bem legal, mas aconteceu o seguinte o meu primo consegui emprego, mas a minha prima não, então tava ficando dificil a fámília se manter aqui, pagar aluguel, luz, água então eles resolveram voltar pra Pampo Grande, fiquei muito triste mas tive que pedir demissão e voltar junto com eles jä que sozinha eu näo tinha como me manter com um salánio... Chas antes como fiz no Q Qio de Saneiro peguei o dinheiro que tinha pra receber 
e comprei roupas, mais cosméticos, presente pra todo mundo lá em $P_{\text {ampo }}$ Grande, inclusive pra minha mäe... $\& u i$ no 1,99 e comprei uma sacola bem bonita e enchi de perfumes, batons, sabonetes, eto e levei pra minha mäe de presente, quando cheguei lá ela nem acreditou que tudo aquilo era pra ela... Pomo eu já imaginava chegando lá não arrumei emprego, nüo tinha emprego...pra näo ficar sem dinheiro comecei a bater nas casas que eu achava que eram mais bonitas e a oferecer senvigo como lavar calcada, passar roupa e assim fui sobrevivendo... Wẫo passou muito tempo e uma vizinha da casa que a gente morava lá em बtajai ligou pra minha prima perguntando se eu não queria voltar pra Stajai para cuidar da netinha dela que ela criava de três anos e de uma filha adotiva que ela tinha de dez anos porque ela teria que comegar a viajar bastante pro Qio de Saneiro em função de um tratamento que o marido precisava fazer já que estava com câncer e nãa tinha com quem deizar a crianças... Ahhh eu pulei de alegria, ela mandou o dinheiro pela conta do marido da minha prima para eu comprar a passagem e eu fui. Doe volta a Qtajai além de cuidar das crianças por incentivo de uma vizinha comecei a freqüentar o "EDSA" para acabar o primeiro e o segundo grau, tava bem feliz, finalmente eu me sentia útil, morando com uma familia, chamava o casal de sessenta anos que me acolhera de pai e mẽe, estava estudando... Até que algo parecido com o meu passado começou novamente a me perseguir, o velho tava bastante doente mas mesmo assim começou a me assediar, quando a esposa dele não tava por perto me pedia e implorava beijo, passava a mão em mim, fingia que tava passando mal pra me chamar pro quarto e me assediar... eu fiquei bastante perturbada com aquela situagâá, porque além dele estar realmente doente, de ser velho eu não queria contar aquela coisa horrorosa pra mulher dele, uma senhora que fazia tudo por ele, me chamava de filha e que tinha me acolhido tão bem...era uma situagãa muito chata... Quando as pessoas tavam perto ele era bem mal comigo, quando elas saiam ele ficava se esfregando em mim... Que martírio... a casa dele funcionava como um quartel, já que ele era ex-comandante da marinha,..., quando ele pedia alguma coisa todo mundo tinha que atender... Pomecei a ver que ele era realmente malvado...A única coisa que me segurava lá era porque ele não ficava o tempo todo em casa, ficava uma semana em casa e ás vezes até duas no Qio para fazzer o tratamento de cầncer... Pom essa situaçäo comecei a ficar muito apreensiva, a mudar o meu jeito de ser... Pomo eu fálei o meu passado tava batendo a minha porta novamente... \&u não fálei antes, mas a própria farmilia que a minha mãe me enviou lá em Osergipe também me assediou, eu tento só lembrar das coisas boas que aconteceram lá, mas lá também eu fui assediada e eu era só uma

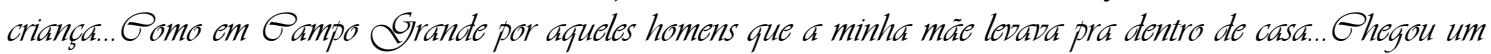
dia em que ele começou a passar a mão em mim e eu dei um empurrão nele, como ele tava "fraco" porque tinha vindo da quimioterapia comecou a passar mal, depois daquele dia nunca mais me incomodou, também nãa teve muita oportunidade, porque um tempo depois ele morreu no Q Rio de Ganeiro... () tempo foi passando e eu já estava na casa dessa familia em Qtajai fazia très anos, terminei o \&OSA, fizemos uma festa de formatura e eu comecei a desanimar porque tinha me formado mas continuava a trabalhar de babá, e depois eu não tinha carteira assinada, a senhora com quem eu morava me pagava direitinho, mas se negava a assinar minha carteira, eu fiquei muito chateada com isso, mas nãa podtia fazer nada, como eu ia botar no "pau" a pessoa que havia me acolhido em sua cassa? Cressa época, logo depois da formatura surgiu uma oportunidade de emprego em \$slumenau, ainda como babá e cozinheira, mas ganhando bem melhor e com carteira assinada, foi dificil pedir demissão pra quem tinha se tornado quase uma familia pra mim, mas enfrentei e pedi. Quando cheguei em Q⿱一𫝀㇒menau fiquei sabendo que ia trabathar na casa de uma médica pediatra que fazia parte de uma familia tradicional do local e morava num bairro nobre da cidade... () prédio tinha um apartamento por andar, nunca tinha visto uma casa tão linda, nem là no Reblon, tinha uma sacada gigante, muitos cristais, sala de piano, quatro banheiros... Era muito chique... () problema foi que eu não tinha carteira de motorista e precisa porque ficania um carro a minha disposigä́o para levar o filho da patroa para as aulas de tênis, piano, inglès, etc...Alquele menino ia se tornar um gênio ou ficar maluco... Também tinha um cachorrinho de raģa que só podia beber água mineral e às vezes eu me esquecia e dava água da torneira, como tinha câmera no apartamento a doutora via o que eu fazia e não gostou... Al gota d' água tanto para mim quanto para ela foi quando um dia que eu tava com tanta alergia, depois descobri que era alergia do cachorro, que ao invés de deizar a cozinha limpa corri para farmácia e nesse meio tempo chegou a irmã dela da Qnglaterra, foi um escândalo, como que eu poderia ter deixado a louga suja? CKesmo eu mostrando pra ela a notinha da farmácia e o meu corpo todo pipocado, até parecia que eu tava com rubéola ela não entendeu, então eu disse que ia embora e ela concordou... fiquei lá mais 
ou menos um mès e meio e lá estava eu de volta em @tajai novamente... Döltei e fiquei morando na casa da mesma fámilia onde eu trabalhava, e moro lá até hoje, mas agora eu não seria mais empregada e sim mais ou menos um membro da familia, ou uma hóspede permanente, alguém que ajudava de alguma forma pagar as contas... Woño continuei a trabalhar na casa pois logo depois que voltei de Cllumenau um colega men do \&OSA arrumou um emprego com salánio e carteira para mim numa empresa que presta senvico para Unniversidade, eu fazia senvicos gerais na área de limpeza, era faxineira. Al universidade era um mundo novo para mim, na época em que eu fazia o \&o SA me perguntavam se eu ia fazer vestibular e isso nem passava pela minha cabeca, já que para mim isso era coisa só de quem tinha dinheiro, mas depois que eu comecei a trabalhar lá vi que poderia tentar... () meu sonho era fazer fisioterapia mas como o vestibular era muito concorrido optei por biotecnologia já que tinha matérias afins e depois eu poderia tentar conseguir uma transferència interna... fiz e passei no vestibular, lá tava eu me achando o máximo, imagina eu uma universitánia, o único problema era quando eu encontrava meus colegas com o uniforme de senvente, limpando o chão, eu nĩo me sentia muito bem, sentia uma certa vergonha, mas tinha que superar aquela

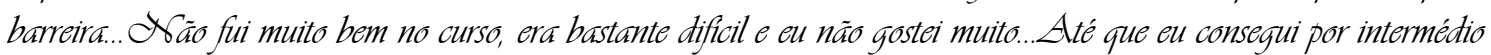
do pessoal de OHistória que mantive contato no EDSA um estágio no arquivo municipal de @tajaí, lugar em que trabalho hoje, estou aqui desde 2004, esse estágio era para trabaithar no projeto "Chemónias dos bairros".. Dra época o professor de Olistória me explicou que como estagiária eu ganharia menos que na empresa de senvicos gerais, mas eu não liguei, pelo menos teria um emprego mais interessante, foi a partir dai que comecei a me interessar por O História, então troquei de curso e hoje estou no quinto periodo da faculdade de OHistória e continuo trabalhando nesse projeto, aqui eu faço entrevistas, transcrevo fitas e me orgulho de trabalhar num projeto que leva em consideragaño a memónia das pessoas comuns que geralmente sãuo esquecidas quando se fala na história da cidade, de um ponto de vista que até então tinha sido esquecido... Tenho muita facilidade em entrevistar as pessoas, principalmente porque são velhinhas, elas se abrem comigo fallam de suas alegrias e suas tristezas, muitas vezes eu me identifico com elas...esse trabalho é muito interessante..

\section{FÊNIX}

Pom a morte da minha irmã minha mãe ficou muito doente, na época ainda nũa se fálava em depressãu, mas acredito que ela teve... Dai ela largou de mãa os filhos mesmo... Eembro que foi horrivel, a sensagẵo de perda da minha

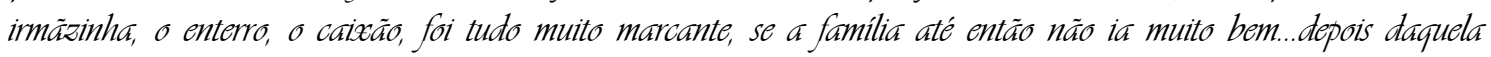
experiència tudo piorou... Poltando a minha adolescência as coisas entre eu e minha mäe ficaram ainda piores quando eu comecei a perceber que o meu pai comecou a me espiar quando eu trocava de roupa, tomava banho...eu bastante incomodada contei pra minha mãe e ela não fez nada...ó fez ficar com mais raiva de mim... \&u nãa consigo entender porque as mulheres se omitem tanto nessas situaçäes, acredito que muitas delas poderiam evitar a violència sexual contra seus filhos se não fossem tão omissas.. Al minha mãe viveu e vive até hoje ao lado de um homem que ela não ama... acredito que mais que brigar comigo ela duelava com ela mesma... Quando eu jâ morava em Osalvador e meus pais iam fazer 25 anos de casado em abril é que caiu a minha ficha que se eu ia fazer vinte e cinco anos em outubro quando minha mãe cassou com meu pai ela tava grápida de quatro meses... Cresse dia passou pela minha cabega todas às vezes em que ela me agredia fisica e psicologicamente dizendo que eu era a culpada dela ter tido que se casar com meu pai... Engragado que desde que eu era pequena ela recriminava as moças que ficavam gránidas solteiras, inclusive eu que nessa época, com vinte e cinco anos, já tinha tido um filho solteira... foi por isso então que ela foi obrigada a casar com meu pai... Dorque criticar tanto os outros se o ato foi dela, não foi de ninguém... Doós não temos uma relação boa até hoje... Então, nessa trajetónia da minha mäe me maltratar eu acabei fazendo as coisas pra agredir mesmo... Quando eu saía se ela mandava eu voltar em tal hora eu voltava mais tarde... Quando eu fui estudar a noite, eu mal ia pra aula e ia dançar... Era proibida de tudo, então fazia tudo escondido... Chuita coisa que aconteceu comigo foi em funçäo dessas proibiçôes, nãa estou colocando a culpa neles, mas fiz um monte de coisa que nãa foi legal pra mim mesma com o intuito de ferílos... () primeiro homem que eu amei, que eu era apaixonada, o 
meu pai me proibiu de namorar, isso porque ele era irmão de uma pessoa que foi presa em 64 por causa da ditadura e meu pai o acusava de comunista, o que pra ele era o fim já que o meu pai foi sempre um homem politico, da situação... Quando eu comecei a namorar esse rapaze eu tinha dezesseis anos, tava acabando o ginásio... for uma coisa bem boa...eu sentia que pela primeira ver na minha vida tinha uma coisa minha, concreta... \& nüo deu certo porque o meu pai näo deixou isso acontecer... foi meu primeiro amor... A partir do nosso rompimento a minha vida comecou a ficar bem confusa...porque mais do que tudo nôs éramos muito amigos... \& u era uma moga, uma mulher muito vistosa, bonita, alta, corpo bonito... Xo começo isso me incomodava um pouco principalmente pelo assédio dos homens, mas depois eu comecei a tirar proveito disso... \& tem uma coisa chamada vaidade...dai a gente acaba tirando proveito... Até tem um episótio engragado que eu e aminha prima cortamos o cabelo bem curto para vender e poder comprar bolsa e sapato de verniz... \& aquele amor foi uma coisa pura na minha vida...tanto que até hoje eu sinto esse amor por aquela pessoa... Eu encontro com ele, ele ta doente, eu fico triste dá gente ter se separado... \& Sẫo tenho certeza que teria sido uma longa história... mas o problema é que a gente nem teve o direito de tentar... \& u ficava revoltada do porque eu não poder ter a vida igual de muitas mulheres, namorar, casar com quem en estava apaizonada, ele era um cara decente, tinha dezoito anos, fazia o exército e o meu pai encontrou meios de nos proibir... Dor que eu me perguntava...porque eles não aceitavam esse relacionamento... \& $u$ näo estava fazendo nada de errado... Ele era o genro que toda mãe e todo pai deveria querer para uma filha... DDepois que não deu certo eu fui estudar a noite e me liberei... Tinha um monte de casa noturna em Qtajaí.. Encontrei uma turma bel legal, tinha umas mogas mais velhas do que eu e outras da minha idade... Sressa época eu usei e abusei de tudo que en tinha direito... faltava a escola.. Tinha um homem que era separado que de vez em quando me dava carona...ele me assediava bastante... Ulm dia ele me deu carona num dia de chuva ele me levou pra praia de Pabeçudas e all a gente teve relaçä́... \&u tinha dezoito anos... foi a minha primeira relä̧ä́o... A gente se conheceu na escola eu fazia normal e ele contabilidade, ele se formou um ano antes de mim... Depois ele foi da primeira turma de formandos de direito de @tajaí.. Sessa relação en engravidei... uma única vez e eu engravidei... foi uma relação bem conturbada porque eu não era nenhuma santa... mas ao mesmo tempo eu ainda era virgem, na hora eu me senti violentada... ele foi estüido...na hora ote eu fiquei com medo e eu desisti, mas ele me segurou e foi e en engravidei... Dai a minha situação ficou dificil... Ose a minha relaçãá com minha mãe e meu pai já era dificil...quando eu fiquei grávida piorou muito... \& eu não aceitava aquela situação de estar gránida...eu tinha minhas ambiçöes, eu queria continuar meus estudos...eu tinha outros sonhos... \& eu sabia que tudo isso seria interrompido ali... \&u não aceitava que tava

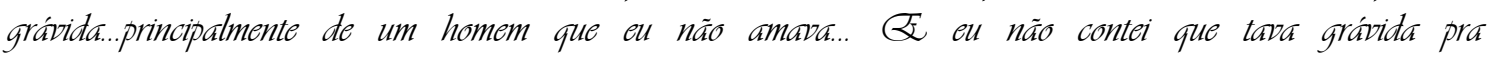
ninguém... Ssegurei a minha gravidez até os sete meses. Al única pessoa que eu contei foi pra ele, pro pai...só que ele

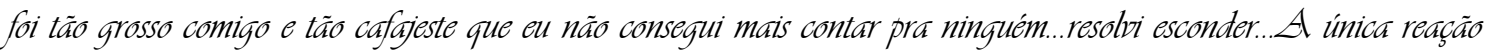
dele foi me levar pra abortar...como não tive coragem, nüo fui, näo fálei mais com ele e deixei o tempo correr e com isso a barriga ia crescendo e eu ia usando cinta e roupas mais largas pra esconder de todo mundo... Chais uma vez eu me

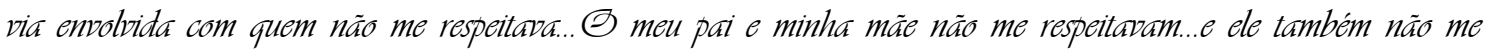
respeitou... foi muito dificil.. (foi muito dificil (choro)... () problema da minha doença não foi tão dificil como enfrentar essa gravidez sozinha... Dai eu me vi completamente só... (choro)... \&u continuei estudando, eu fazia tudo normal... Ssó que eu tinha o corpo muito bonito e comecei a engordar... W a minha cabeca ia acontecer alguma coisa mágica que aquilo ia ser interrompido...e nu não aceitava aquilo... W a a época nós tínhamos a disciplina de educacaũo fisica, dai um dia na aula de educação fisica as outras alunas mais velhas ficaram olhando pra mim e fofocando e logo depois eu fui chamada na sala do diretor e elas estavam lá..e perguntaram pra mim se eu tava grávida... \& falaram... falaram. ofoi uma conversa horrorosa...constrangedora... Dai eu disse que a minha mãe nã̃o sabia... \& aquilo na escola todo mundo ficou sabendo... Dai o diretor ficou de ir conversar com a minha mäe junto comigo, porque provavelmente iam me colocar pra fora de casa... E ssa conversa na escola foi numa sexta-feira e o diretor ficou de ir na próxima semana na minha casa... Ssó que no sábado a minha mãe foi ao mercado e lá ela ouviu alguém comentar com outra pessoa sobre a minha gravidez e a minha mãe escutou..A minha mãe quase morreu... Daí o meu diretor foi conversar com ela e eles deixaram eu ficar em casa... () meu pai näo me aceitou, mas mesmo assim eu continuei dentro de cassa.. Dai a minha vida ficou um inferno total... Plaro, algumas pessoas me ajudaram, da própria 


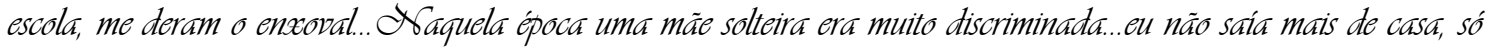
vivia pra estudar... Dorque na escola quando ficaram sabendo da gravider me trataram bem, de lá eu nãa posso reclamar... Ssó parei pra ter o bebê... A minha mãe me acusa até hoje por aquela gravidez, mas acho que eles também poderiam ter me ajudado no sentido de procurar o pai e ter pedido para ele tomar uma posigzāo... Chinha mãe ficou com vergonha e comegou a andar de cabecga baixa... () neném nasceu e já na outra semana eu retornei pra escola pra acabar o segundo grau... Pomo tava muito dificil de emprego, principalmente pra uma mãe solteira, surgiu uma oportunidade que eu não podia deizar passar... Zlma instituicãa em बtajai tava oferecendo très vagas para trabalhar com a comunidade, só que para isso teria que passar por uma seleção e se passasse teria que fazer um curso de capacitagä̃o em assistencialismo no Qio de Ganeiro, dentre mais ou menos 500 pessoas eu fui selecionada, minha

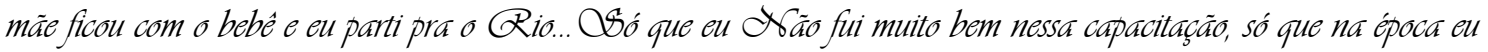
fiquei sabendo que tinha uma outra vaga para professora de jardim de infäncia, e eu me identificava mais com isso, porque a minha formação era normalista, eu tinha habilitaçãao pra dar aula... Dai eu consegui permanecer no Q Qio de Saneiro e fazer esse outro curso de capacitação pra jardim de infância... Đai eu fiquei mais um mês no Q Qio, no

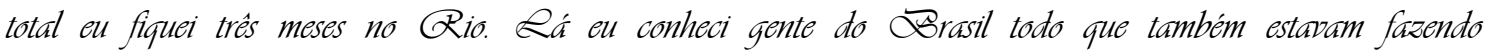
capacitaçấo... \& naquele curso eu fui muito bem... Dai surgiu uma vaga em Stabador na área do curso que en tinha feito, para @tajai nãa tinha previsãa... (O) salánio era bom, eles pagavam todas as despesas... Đai eu voltei pra casa em बtajai e disse para minha mãe que eu ia pra Ssalvador, ela não aceitou, mas eu disse pra ela que eu iá, ia me estabilizar lá e voltava pra pegar o menino... Qsso era 1973. Dai comegou uma outra etapa da minha vida... Ulm ano e pouco depois eu vim buscar o menino e a minha mãe jâ não deizou mais eu levar... As coisas na cabeca dela já tinham mudado muito, pra ela a mãe dele era ela e o pai dele era o meu pai... Depois quando ele já tava maiorzinho eu vim buscar novamente, mas nã̄o consegui levá-lo... Dai eu trabalhando naquela instituiçä́ em Qsalvador eu conheci um novo amor... Era uma pessoa que fazia medicina e uma vez por semana ia até a instituigäa fazer estágio e atender as crianças carentes... Quando a gente viu a gente começou a namorar... Samoramos algum tempo e eu voltei a engravidar... Ssso depois de très anos do meu primeiro filho nascer... Doós tivemos um romance bem louco... Dorque se aqui em @tajai, era tudo proibido, era pecado, lá na época era tudo liberal... Era uma vida completamente diferente daqui... foi um amor misturado com paizäa... f foi uma coisa muito maravilhosa... Quando eu fiquei gránida ele me colocou num apartamento, a mãe e a irmã dele nos apoiaram, mas o pai dele não... Tava preocupado com a faculdade dele e foi contra que nós morássemos juntos... Exntão ele só ia me visitar nos finais de semana, mas era uma época muito complicada, ele tava fazendo residència...tinha que estudar muito... \& tinha uma outra coisa que comegou a estragar nosso relacionamento...ele me tratava como uma princesa... mas era extremamente ciumento...até as compras vinham até minha casa... \&u não podia sair nem a pé, nem de ônibus, só de táxi... nãa podia conversar com ninguém... E isso ia contra o que eu sou...bem comunicativa... gosto de conversar com todo mundo... Depois que o bebê nasceu e jấ tinha 9 meses nốs tivemos uma discussãa muito feia e rompemos... E\& le não abandonou o filho, a criança sempre ia pra casa da avó... Chas nốs nunca mais voltamos. Ali eu sofri muito também, porque eu gostava dele... Cressa época eu arrumei um emprego numa tecelagem eu secretariava a producáä... ofiquei um bom tempo nessa empresa... Até que um homem mais velho se apaizonou por mim, quis ficar comigo mais eu recusei, não gostava de homens mais velhos, mas mesmo assim ele comecou a me proteger e arrumou um emprego melhor pra mim numa empresa de seguros, na época essa empresa dava boas oportunidades... Oomo eu tava melhor financeiramente voltei pela terceira vez pra Qtajai pra buscar meu filho, mais uma vez meus pais recusaram e dessa vez ele próprio não quis ir comigo... E le já tinha 5 anos, embora eu nunca tivesse o abandonado completamente, mandava sempre presentes e dinheiro, minha mäe o colocava contra mim, dizendo que eu o tinha abandonado, não explicou que eu tinha ido trabalhar e que por outras vezes já tinha ido buscáto, assim o menino cresceu me odiando... Dassou mais um ano e eu ainda trabathando na empresa de seguros em Dsalvador eu conheci um outro homem, que foi meu marido por 23 anos... \& u conheci o Qobento numa festa na casa de uma amiga minha... Eogo depois nos fomos morar juntos, e logo ele também foi trabalhar na mesma companhia de seguros que eu trabalhava... Dessa vee não era paxião, mas nós nos gostávamos, e o melhor é que ele me aceitou do jeito que eu era... Ele aceitou que eu jấ tinha dois filhos... Ele era filho adotivo, sofreu bastante na vida também, então 
resolvemos ir morar juntos... Q Sós moramos um tempo junto, depois nós casamos no civil e no religioso... Tivemos uma vida bem sofrida juntos ele era violento...bebia... Depois de algum tempo ele foi trabathar na mesma companhia de seguro que eu trabalhava... Ele mudava muito de personalidade... \& ele foi se revelando um homem violento aos poucos... \&le não podia ser contrariado que virava bicho...

Qecapitulando: \&u morei em Satbador durante cinco anos, conheci o pai do meu segundo filho e me relacionei com ele durante uma ano... Depois que eu me separei dele eu conheci o pai do meu terceiro filho e vivi com ele durante vinte e trés anos... Ponheci ele numa festa, ele me envolveu, ele me valorizava muito... Al fomos viver juntos, ele sempre quis noivar, casar, queria ter uma relaçäo bem certinha comigo... \& u é que era meio assim...meio...eu näo queria casar... \& $u$ tinha medo de me casar... \& le foi se revelando aos poucos, era bom, cuidava de mim...quando nos conhecemos ele estudava, trabalhava, fazia faculdade, mas jâ tava largando... ele era jogador de futebol... Depois que agente conviveu e hoje eu penso, que ele tinha um disturbio de comportamento, na mesma hora que ele tava bom, logo ele mudava de compontamento... Ele nunca sabia o que ele queria, ele comegava uma coisa e não terminava... Ele teve bons empregos... Ele era um homem extremamente inteligente... Quando eu o conheci eu trabalhava numa empresa de seguros e levei ele para trabalhar comigo... Ele nunca tinha visto seguro, e em uma semana de curso ele superou todas aquelas pessoas que já trabalhavam na área, em pouco tempo ele foi ser instrutor de seguros no norte e nordeste do Brasil... Então ele ficou com um alto salánio, logo depois disso formos morar juntos e nos mudamos para

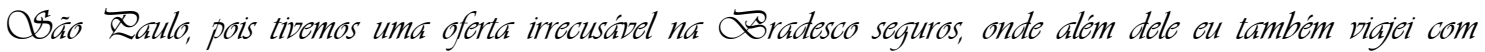
emprego garantido... Choramos sete anos em Stäo Daulo, e já no início tivemos grandes problemas, pois ele perdeu o emprego dele por causa da bebida, por causa da irresponsabilidade dele, porque dai ele bebia a noite e nãa acordava cedo pra ir trabaithar... chegava atrasado... \& a disciplina do banco onde nôs trabalhávamos era muito nígida... \& $m$ primeiro lugar toda pessoa que vem do nordeste já tem um rótulo, tem que provar que é cem por cento bom...nãa pode ser noventa e nove por cento bom, tem que ser cem por cento... \& $m$ Csäo Daulo todo mundo fála: é baiano mesmo, só farz baianada... \& ele acabou farzendo não só baianada, mas um monte de "caca", e nisso eu continuei trabalhando, eu trabaithei sete anos no banco, só sai quando voltei pra OSanta Patarina... \& le perdeu o emprego em meses... Depois ele entrou em outra companhia de seguros e foi ser vendedor de seguros em todo interior de QSĩo Daulo... Wa á época nós morávamos na grande Qsião Daulo em (Osasco, dai nós compramos uma casa boa, eu engravidei novamente, antes disso eu havia feito um aborto em Stabuador, pois ele näo queria ter o filho, nós estávamos brigando muito e eu resolbi abortar... \&á nessa terceira gravidez desse foi a melhor fase que nốs vivemos juntos, ele tinha isso, tinha época em que ele era maravilhoso, acho que foi por isso que consegui viver vinte e três anos com ele... E ntẫo, no oitavo més da gravidez do meu terceiro filho eu estava em casa sozinha porque ele tava viajando pela seguradora eu passei mal, fui pro hospital sozinha, corri risco de vida e perdi o bebê, foi muito triste, porque esse filho tinha sido planejado, nôs estávamos esperando por ele, quando ele voltou de viajem fizemos o enterro, foi muito triste... Chas dai aconteceu que logo depois dessa perda eu engravidei novamente.. W a verdade, eu gosto de filhos, eu acho que eu nãa gostava era de marido, mas de filhos eu gosto, se eu pudesse eu teria mais filhos... Ssen gosto dessa

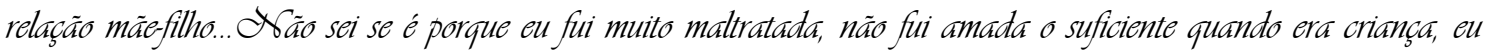
tenho um amor bem diferente pelos meus filhos... \& u näo dei pro primeiro, talbez porque nós fomos separados, mas pros

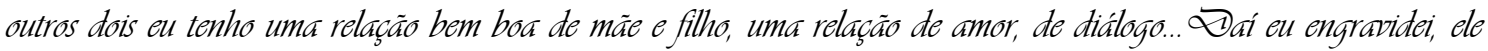
não queria que eu tivesse esse filho, acho que porque eu tinha quase morrido na gravider anterior, mas eu quis ter e tive enfim o meu terceiro filho... Qsso aconteceu no quarto ano em que eu estava em Stão Daulo, essa foi a minha quinta gravidez e ai eu tinha vinte e nove anos... Durante essa gravidez aconteceu um episódio bem ruim, eu tava grávida de três meses e nas férias nós resolvemos ir para Osalvador visitar a familia dele... Ohegando lá formos a festa de "largo", que é uma festa típica que acontece em Ssalvador... eu fui na verdade na lavagem do Bsonfim no comego de janeiro, essa é uma festa muito tradicional, nessa época ele bebia muito ainda, depois de percorrer a trajetória da festa que vai da Ponceiçã̃o até o SBonfim, fomos pra casa da irmã dele que mora no Sonfim... Ele me deixou là e resolveu sair sozinho, ai ele já tava bebendo e ele era assim quando saía, sumia dois, trés dias e gastava o dinheiro todo... Dessa ver eu peguei o dinheiro que era do meu salário e guardei sem ele saber, depois de beber todas, ele foi pagar a conta pensando que tava com o dinheiro e quando viu tava sem nada... Ele voltou pra casa da irmã muito 
bravo...e quando chegou mesmo eu estando gránida, ele não pensou duas vezes e me bateu muito e ai eu não pude reagir por causa do meu estado... Che bateu na frente de todo mundo e ninguém fees nada, eu fiquei com muita chateada naquele dia, muita raiva...porgue nessas brigas geralmente eu apanhava, mas ele apanhava também, eu revidava... mas por causa da familia e da gravidez eu fiquei quieta... dai eu consegui fugir, peguei uma carona com uma Qombi e fui pra casa da minha sogra, cheguei lá toda machucada e ela não deizou ele entrar. Ofoi muito dificil..então naquela noite eu dormi no apartamento da vizinha da minha sogra para que as coisas se acalmassem... Wo outro dia compramos as passagens de avião e retornamos para Stão Daulo... X Sessa trajetónia toda de violéncia eu tentei muitas vezes me separar, mas não conseguia, näo tinha forģas pra isso, ele pectia perdão, ele dizia que me amava, dizia que não ia fazer mais, mudava, ficava bom... dali um tempo comegava tudo de novo... Durante essa nossa viajem pra SSalvador aconteceu algo muito triste e estranho em Stão Daulo, o chefe dele que era uma pessoa que ele amava bastante que viajava junto com ele pra vender seguros, foi levar a mäe numa viajem e enfiou o carro em baixo de uma carreta e morreu, logo em seguida, quando retornamos pra Osão Daulo, o outro colega dele que viajava também junto com ele, numa viajem de treinamento com um novo funcionário que ia tomar o lugar do chefe também sofreu um acidente de carro e morreu... Ele ficou muito mal, perdeu os dois companheiros de viajem praticamente juntos, ele ficou com medo de viaja, ficou assustado, ficou totalmente desiquilibrado e resolveu pedir demissão... E ele era assim, quando ele ficava desempregado, dava uma coisa nele, que ele ficava um mès, dois meses só deitado... OHoje eu entendo, acho que devia ser uma depressãó, alguma coisa assim... Ya ápoca eu dizia pra ele, vamos no médico, vamos no psicólogo, mas ele nunca quis ir... X ra raiva eu dizia pra ele que ele era maluco...ele ficava muito enfurecido quando eu dizia isso... STessa época quando ele ficou desempregado, ele ficou numa loucura tão grande que ele me deixava trancada dentro de casa que eu não conseguia nem sair pra trabalhar ìs vezes... \& as crianças ficavam participando dessa loucura toda, e eu ficava sustentando a casa, porque quando ele ficava desempregado eu é que tinha que sustentar a casa sozinha...sempre eu, porque também muitas vezes quando ele tinha dinheiro ele bebia quase o dinheiro todo... Dai numa dessas loucuras que ele tava desempregado nós fomos assaltados... E Entrou cinco homens dentro da nossa casa em - Osasco e levou tudo que a gente tinha... \& ra noite eu tava na cama dormindo, ele tava na sala assistindo televisão, bateram na porta e ele abriu e eles entraram todos armados... Wessa época o mais novo tinha um ano, um deles ficou o tempo todo com uma arma apontada pra cabega da crianca, ameagando, se a gente fizesse barulho eles atirariam na crianca... Eles ficaram da uma hora da manhã até umas trếs e meia... Eevaram tudo, tudo que agente tinha dinheiro, roupa, comida, eletrodoméstico, eletrônicos...levaram tudo... Lli eu fiquei muito desesperacta, muito apavorada, muito angustiada... fiquei meses ouvindo a voz daqueles homens na minha cabega... foi desesperador... \& o medo nessa época em Osão Daulo é que eles entravam nas casas estupravam as mulheres na frente dos maridos...eu fiquei com medo que fizessem isso comigo, mas nüo fizeram... Eram pessoas bem arrumadas, alinhadas, nũo tinham características de bandidos comuns... Ai eu fiquei muito desanimada de morar em Stão Daulo... \&u jấ sofria com marido, já era violentada quase que diariamente (quando ele bebia eu nãa queria ter relaçấo e ele obrigava a ter isso é uma violència...pior que essa violéncia pra mim não tem...e é do tipo do homem que se a mulher é casada não pode negar nada, tem que aceitar tudo.) e ainda aconteceu isso tudo... \& u tentei muitas vezes me separar, muitas vezes eu chegava a fugir, ele me achava, me trazia pra dentro, fazia algumas chantagens emocionais, porgue tinham as criancas... Depois do roubo nã̄o consegui mais pagar meu financiamento, nã̄o tinha mais estrutura emocional e fui mandada embora do banco, além da questão financeira que ficou péssima, eи e meu marido desempregados e sem nada, eu fiquei com muito medo de continuar morando em Stão Daulo, não queria mais criar meus filhos lá, entã̄o depois de sete anos morando lá fomos embora pra Osanta Patarina, lá estava de volta em Qtajar, minha cidade natal... A minha mäe continuou não me aceitando... Do meu marido e filhos ela também nä́ gostava, como ela é uma pessoa extremamente preconceituosa, não aceitava que os meus filhos e marido fossem descendentes de negros... Ste ela não gostava de mim antes de eu ir embora, quando retornei casada e com filhos negros ela passou a não gostar mais ainda... \& pior ainda, eu retornei doze anos depois desempregada, pobre, comecando tudo de novo.. Ohegando aqui, já que ao longo da vida tinha feito alguns cursos, comecei a fazer artesanato para sobreviver $e$ também comecei a trabathar na prefeitura como professora do primánio, também arrumei emprego para ele na prefeitura, 
ele foi ser professor de matemática, depois ele passou pra dentro da prefeitura... mas por irresponsabilidade dele perdeu também esses empregos... E le não parava em lugar nenhum... As bebidas, violèncias, brigas em @itajai foram muito fortes, fortes, fortes... ofoi dificil... \& eu trabalhando na prefeitura eu fui crescendo, fui primeiro professora vinte horas, depois quarenta horas, depois me chamaram para ser coordenadora... Eu sempre fui uma pessoa muito esforcacta... Quando eu trabalhava no desenvolvimento social, e a gente era responsável pelo carnaval, pelas festas todas em Qtajai... ele saiu pela manhã pra ir buscar nossas camisetas de trabalho na prefeitura para a gente ajudar no desfile ele voltou pra casa seis horas da noite completamente embriagado... Dai eu resolvi que eu não ir... \& sse dia foi horrivel... Chas antes disso nós tivemos muitas brigas feias... muita bebida... Teve uma ocasiä́o ele sumiu trếs dias, en fui até a policia, falei que ele tinha sumido... \& ele trabathava na prefeitura junto, e ele nãa aparecia $e$ as pessoas cobravam... Depois o delegado o encontrou... Ele tava pelas ruas, bebendo em boates, botecos... \& le era assim, sumia de repente, dessa vez ele estava trazendo as crianças da escola para casa e no caminho disse pra elas que era pra elas irem pra casa que ele tinha que comprar carne e voltou só depois de três diass... dali ele ia pro bar, bebia todo dinheiro que tinha...penhorava tudo e ás vezes voltava só de cueca pra casa... Dendia roupa, vendia sapato, vendia relógio... Ele era assim... Ele tinha muito ciúmes de mim, ciúmes dos filhos, ciúmes da familia... Era um homem extremamente ciumento... \& $u$ nunca vi ele andar com outra mulher, nunca soube... CKesmo depois que a gente tinha carro, tinha comércio, ele não dava carona pras mulheres da rua, da redondeza... \& eu tentava me separar e nada...e brigas horrorosas... Boltando a histónia do carnaval, ele chegou completamente bébado... Quando ele chegou completamente embriagado, nós brigamos, ele me agrediu uma agressão fisica gigante, nós fomos até pra rua brigar... a dona da casa que nós alugávamos morava pento, veio no meu socorro, bateu nele, ele pegou nosso filho mais novo e sumiu com ele...depois fiquei sabendo que ele tava com a criança na pracinha... SVisso fui até a casa de uma amiga minha e ela conseguiu pegar o meu fiho dele... Desse dia em diante eu não quis mais ele... Al eu decidir me separar dele completamente... \&le foi me procurar na casa da minha amiga eu nãa deixei ele entrar, eu não quero, eu nãa quero ir pra casa eu dizia...e nu não volto nunca mais...ñão quero... dai ele disse pra mim voltar pra casa que ele

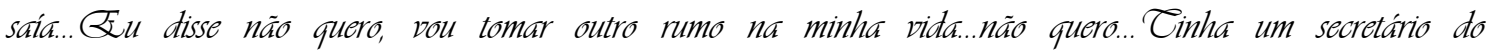
desenvolvimento social que era ex padre da igreja católica e era casado e padre da igreja ontodoxa que era amigo dele, ele foi pegou as roupas dele e foi até a casa desse amigo contar o que estava acontecendo, que agente tava se separando, que eu não queria mais ele, tal e tal... Đai esse padre veio conversar comigo e me convenceu a voltar, mas eu não queria voltar... Além de padre da ontodoxa ele era espinita cardecista... (E) u sou espinita, mas acredito que a gente tem um leque bem grande para mudar a vida da gente... \&u acho que eu nãa mudei a minha vida porque eu nã̄o quis... Depois que eu tirei a venda dos e percebi que as pessoas fazem com a gente aquilo que a gente permite, as coisas boas e as coisas ruins a minha vida comecou a mudar muito. Ali ele se propôs a levar o fulano pra doutrina espirita pra assistir palestra para ele parar de beber... E ele disse que desse dia em diante ele não ia beber mais, e realmente daquele dia em diante ele nunca mais bebeu bebida alcoólica... \& $u$ achava que o grande problema dele era bebida... doce ilusãá... Depois disso ele ficou bom durante um ano mais ou menos. Xessa época a gente tinha até medo de sair pra alguma festa porque tinha medo que ele bebesse... Depois de um ano, ele sempre encontrava alguma

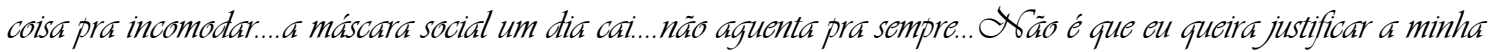
vivència com uma pessoa dificil por esses anos todos, mas hoje eu acredito que ele tinha alguns distúrbios...pela própria história dele...nãa por ter sido filho adotivo, mas porque ele foi criado muito sem amor, sem carinho... Toodos os irmãos da familia tem problemas, a irmã dele tem depressãa profunda, hoje ela ta com 150 kilos... CKáis ou mesmos um ano ele ficou uma pessoa boa, uma pessoa boa de lidar... Dai nesse ano eu continuei trabaithando na prefeitura, consegui um cargo melhor, ele recomegou a trabalhar como vendedor, a gente só se via no final de semana porque ele viajava para vender, adquirimos algumas coisas... Dressa época tava tudo bom, foi um ano, um ano e meio mais ou menos de bastante trangüilidade... Chudou o prefeito eu fui promovida, a nova secretánia era minha amiga e me chamou pra trabalhar com ela... Ulm vereador que assumiu um cargo em outro bairro pediu pro prefeito para que eu fosse trabalhar com ele...mas eu não gostava muito da postura dessa pessoa que eu trabalhava junto com o prefeito, eu ficava bem incomodada com o que eles faziam... Ainda disse pra eles se não fosse o meu salário eu ia pedir exoneração do meu cargo, porque isso ta me incomodando... Depois disso não agüentei mais muito tempo e sai da prefeitura... Do sisso eu e 
o meu marido comecamos a trabalhar juntos, ele saiu da empresa que ele tava trabalhando também... X 60 comego não deu muito cento o que tentamos fazer com o dinheiro da nossa exoneraçấ, encontramos uma pessoa que trabalhava com antefato de madeira, logo no segundo mês o sujeito nos deu um golpe e tivemos que partir do zero mais uma vez... Dai comecamos a pensar o que a gente ia fazer, os dois desempregados... Dai comprei uma revista "pequenas empresas, grandes negócios" e achamos ali a idéia de vender batatas fritas e comecamos a fritar e a vender batatas... Wa primeira semana eu fritei no fogãa normal, eu levei trés dias pra fitar um saco de batatas e ele vendeu numa hora tudo... Dai partimos pra uma fritadeira, depois duass.. E ra um trabalho exaustivo, cansativo...chegou uma época em que eu fritava dois sacos de batatas de 50 quilos por dia... \& $u$ fritei batatas durante dois anos, tive essa pequena empresa por dois anos... Xraquele periodo aquelas brigas homéricas nãa aconteciam, a gente só se desentendia por causa de negócios... Xessa época a gente só tinha briguinhas normais, não era aquela coisa toda... foi um tempo legal... A pequena empresa foi crescendo e nós aplicamos o capital de giro na compra de um carro pra um parente nosso sair pela cidade vendendo batata, quando vimos gastamos todo o dinheiro do capital essa pessoa nãa trabalhou legal, fomos enganados mais uma vez, dai cansamos e paramos de vender batatas, lá estávamos nốs mais uma vez tendo que recomegar do zero... Oresse meio tempo eu havia ganho da prefeitura um terreno no bairro 叉ró-Chorar, fomos até e começamos a pensar o que a gente podtia fazer naquele terreno sem ter dinheiro, e entäo tivemos a idéia de montar um "sacolão"... Pomo nãa tínhamos recurso ficamos dois dias no mato numa área que tinha bambu, contamos bambu, cerramos... Ponsegui um caminhão da prefeitura pra ir buscar o bambu pra mim e eu e outro senhor que trabalhava na prefeitura e eu e ele montamos com os bambus a estrutura para o "sacolão" e inauguramos ele na véspera de natal... Pompramos um caminhä̃o de mercadoria fiado, isso era década de 1990... \& ai eu comprei demais e sobrou muita coisa... Ali eu ainda aproveitei muita coisa pra vender no ano novo... \& fui comprando mercadoria e fui pagando o que eu devia. Xessa época o meu marido comegou a ter novas crises...comegamos um novo período de vida infernal... Era muito trabalho, no inicio cobrimos a estrutura de bambu com uma lona preta abríamos o sacolão só nos finais de semana, depois eu consegui vender uma máquina grande de fritar batatas e consegui fazer a cobertura, então comecamos a trabalhar todos os dias, a vender além de frutas e verduras alguns produtos de primeira necessidade... Era muito cansativo, e a única coisa que meu marido nesses perióodos de desânimo dele fazia era ir uma vez por semana com um caminhão alugado buscar mercadoria no PELAOSA em florianópolis descarregava quando chegava e eu fazia o resto tudo sozinha, era muito cansativo, pois tinha que acordar muito cedo todos os dias, morava longe do sacolão... X Vessa época as grandes brigas recomecaram... E $u$ muito cansada, não tinha mais ànimo pra fazer as coisas em casa, não tinha ânimo pra nossas relaçöes intimas de homem e mulher...muito cansativo... A gente só brigava, mas até ai não tinha mais aquela violència fisica, era nas palavras, violència psicológica... Chas fomos tocando...compramos um carrinho velho, um fiat para irmos durante a semana buscar mercadoria nas redondezas, tempero verde, alface, etc... Ali no inicio do segundo ano do "sacoläo" uma senhora ofereceu uma casa de madeira pra gente comprar pra botar no lado do sacoläo nosso terreno, dai a gente não ia mais precisar pagar aluguel e ia morar no lugar do negócio... Da no no final do ano juntamos um dinheirinho compramos a casa de nadeira, contratei uma empresa que carrega a casa de madeira inteira de um lugar pra outro, botaram no lugar, construimos o banheiro e ficamos morando ali... Dai já era melhor, jấ estávamos morando ao lado... Dai fomos, trabalhando, fomos brigando, fomos nos estressando, tudo com muita dificuldade... \& le me exigia muito e não fazia nada... \& le dormia muito e ele nãa fazia nada... Eu trabalhava de segunda feira a domingo ao meio dia, depois eu comprei duas assadeiras e comecei a vender frango aos domingos no sacoläo... Dai no domingo eu ficava até nove, dez da noite temperando e recheando em torno de quarenta frangos pra assar no domingo...depois trocamos de carro, e eu é que fazia tudo, eu é que trocava de carro...en fazia tudo... Oompramos uma "Topic", chegamos a viajar com ela umas duas vezes até OSabvador... Depois de uns três anos de sacoläo eu passei em janeiro a tirar uns dias de fêrias pra descansar um pouco, senão näo tinha estrutura pra agüentar... \& ele ficava sempre muito doente, ou era doente fisico, ou psicológico, se fechava, dormia muito, ele tinha problema de rins, era problema de estômago, era dor de cabega, era

\footnotetext{
${ }^{2}$ Sacolão é o nome dado na região para uma espécie de feira permanente de frutas e verduras vendidos na sua maioria por um preço popular único. Esse nome faz referência ao uso de uma única sacola grande onde os compradores alojam suas frutas e verduras e ao final da compra pesam tudo numa única vez já que o preço do quilo dos alimentos é o mesmo, raras exceções.
} 
gripe... \& sempre uma pessoa muito amarga... Chinha família não se dava com ele, quase ninguém gostava dele... Dor toda nossa história, porque eles sabiam que ele me maltratava... Dassou-se uns seis anos e chegou um dia que eu nã̄o suportei mais...trabalhamos nas eleigües perdemos... Dai fechamos o sacoläo... De novo estávamos a

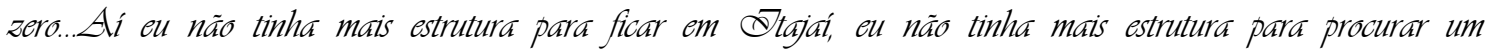
emprego... Quem trabalha por conta própria fica fora do mercado de trabalho, fica sem estudar, fica desatualizado, fica mais dificil arrumar emprego, ainda mais quando jä passou dos trinta anos... Fica muito mais dificil... Dai o que que eu fiz, resolvi voltar pra Ssalvador... Dorque na verdade eu tava como querendo fugir, mas na verdade minha intençäo era me separar porque nós brigávamos muito... \&le era muito ciumento, tinha ciúme de todo mundo, dos meus filhos que já estavam grandes, da minha familia, de amigos, eu não podia sair num domingo a tarde pra ir na casas de um parente, quando eu voltava ele tava de cara amarrada..já era briga pra semana inteira... \& além do mais nossa vida era cheia de altos e baixos, era muito altos e baixos .. era muito dificil.. Tinha tentado me separar também nessa

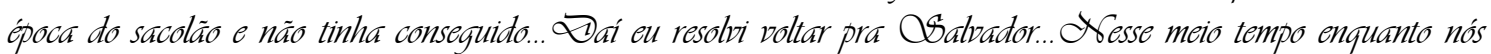
não conseguiamos vender o terreno onde morávamos em @tajai meu filho do meio voltou para Osalvador antes da gente e arrumou um emprego lá, alugou uma casa e enviava algum dinheiro pra gente ir sobrevivendo ainda $\mathrm{em}$ Qtajai e eu fui ajudar minha prima a fazer salgactinhos e congelados pra fora, isso durou alguns meses até que vendemos o terreno por um prego baixo e voltamos todos pra Osalvador... Ohegando lá fomos morar junto na casa que meu filho tinha alugado e montamos um bar, isso era final de 1997 .. de noite funcionava como bar e durante o dia funcionava como restaurante-bar... \& $u$ faria almogo... \& $u$ trabathava das nove da manhã as três da madrugada, eu e ele de novo, ele näo bebia, mas as brigas homéricas continuavam... \& eu trabalhando... \& eu cozinhando... \& eu limpando... \& ai logo quando nós abrimos o bar ele ficou muito doente, ele ficou gravemente doente... Drimeiro ele teve um mal estar muito grande, depois ele teve herpes e depois ele não conseguiu mais se recuperar... Dai uma doenca em cima da outra... Alinda quando nốs tínhamos o sacolẫo ele um dia teve um problema muito grave no estồmago ... 0 médico começou a examinar e aquilo que ele tinha era aquilo que se chamava "sapinho", e aquilo era característico de

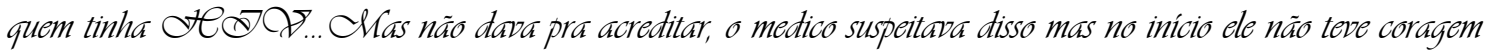
de fazer o exame... Chas a auilo ficava martelando na minha cabeca... Dai fizemos o exame os dois e deu positivo pros dois... não contamos pra ninguém, ficou só entre nós e os meninos, ficamos sabendo em 1995 \& foi assim: o médico conversou com ele perguntou se ele era usuánio de draga injetável e coisa e tal e ele disse que não, que nunca tinha usado droga, e então o médico disse pra ele que pelo quadro dele ele poderia estar com deveria fazer o exame... Quando ele chegou em casa e me disse isso, eu falei não né..tudo que jä me aconteceu isso nãa né..isso não... Lli ele fer o exame, telefonaram pra mim pedindo pra ele repetir porque tinha dado positivo... Ali eu fui fie o exame e deu que eu tinha também... OKas é dificil a gente acreditar... \& u tinha tido outros homens, mas eu tava vinte e poucos anos casada com o mesmo marido... nunca trai ele...e tenho certeza que ele teve essa doença depois que agente tava junto, depois que o meu filho mais novo nasceu, quando tivemos o diagnóstico o meu filho mais novo já tinha catorze anos... Os meninos não tem eles sãuo doadores de sangue... X'ó́s fálamos pros meninos o que estava acontecendo... Até quem me levou pra fazer o exame foi meu filho... Chas como eu tava bem de saúde, tu não acaba acreditando...é uma coisa assim...por tudo que eu tinha passado e ainda passar por isso... E $u$ não acreditava naquilo... E fomos embora para Stabuador... Ali quando nós chegamos lá, eu sempre falava pra ele, vamos comegar a

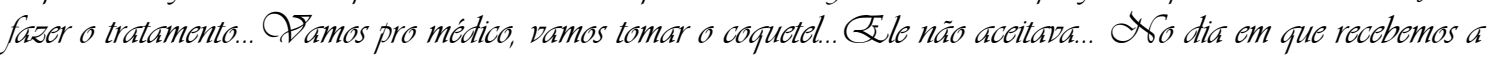
noticia de positivo ainda em Qtajai eu tava limpando o sacoläo, quando ele chegou a gente pegou o carro e saiu, fomos lá para beira-Qio, quando chegamos lá eu chorei muito... faleil ofulano porque tu fizesse isso comigo, porque tu andasse com outras pessoas... Ele fálou que näo transou com outras... Ali en falei pra ele: 叉elo amor de Deus... \&u chorei, chorei, chorei... Ai ele falou que os exames estavam errados... Ali eu disse pra ele que estavam certos porque a gente tinha feito duas vezes... \& ele nũo aceitava, nã̄o aceitava... \& u fui embora realmente foi para ver se lá numa outra cidade que ninguém conhecesse a gente, ele teria coragem de ir pro médico e fazer o tratamento... isso seria o certo... Sá que não tinha se manifestado nenhuma doença em mim, e ele tinha tido algumas pequenas doenças em consequếncia disso, se nós tivéssemos feito o tratamento nốs teríamos evitado muita coisa dai como ele se negou a fazer o tratamento eu telefonei pro irmão dele e contei pro irmão... mas não actiantou... Q quando 
nós formos trabathar no bar ele ficou muito doente, muito doente mesmo... \& ele foi ficando doente, doente, doente... Fui ficando no bar sozinha... Dेẫo deu mais pra tocar o bar... Dai eu fechei o bar, dai ficou en e ele desempregado... Al gente sobreviveu nessa época com a ajuda do irmão dele, o meu filho do meio trabalhava e ajudava e eu fui fazer faxina em Ssabvador.. Trabalhava num restaurante final de semana como ajudante de cozinha, lavava prato, descascava batata, eles não sabiam das minhas habilidades culinánias, eles já tinham cozinheiro... \& depois eu sou branca, do sul, e o dono do restaurante teve até medo de me empregar, pois achou que eu era uma espiẽ para montar outro restaurante...porque o restaurante dele era típico gaúcho e ele tinha medo de mim, me tratava mal, me tratava mal mesmo por isso... \&u me submetia a aquilo tudo, bem humilde, nã̄o dizia que eu sabia cozinhar, nãa dizia nada, porque lá no restaurante eu comia bem, tomava café da manhã, almogava e saía praticamente jantada e trazia o dinheiro pra cass... Quando tinha feriado, algum evento eles me chamavam, eu ia todos os domingos... \& o meu marido foi piorando, foi ficando cada vez mais doente, foi ficando muito ruim, muito violento... Chuito dificil, de agredir a gente, de agredir o meu filho mais novo (Quando ele me agredia eu batia em cima, eu sempre tinha um pau esondido em qualguer canto da minha casa, quando ele vinha bater em mim eu dava pau nele... Ás vezes as pessoas viam que ele batia em mim, de manhã eu saía bela e formosa pra trabalahar e ele tava todo quebrado em casa,

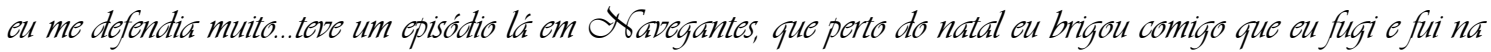
delegacia ele foi preso eu fugi passei uns dias em \$Blumenau, depois eu voltei pra acabar tudo e ele pediu até ajuda pro delegado pra fallar comigo pra gente voltar...era assim uma coisa bem louca... \& $u$ sempre me defendia .quando ele vinha pra cima de mim eu empurrava ele, ihhhhhhhhh....... \& ele foi piorando... \& u pensei que ele ia morrer, dai en chamei o irmão dele, internamos ele e ai ele jâ tava com tuberculose, ai a doença se manifestou bastante.. Lli se ele era ruim, com isso ele ficou mais ruim ainda... ficou insuportável a sobrevivència ao lado dele... Ai eu não fiquei doente, fui trabalhando, trabalhando... Era pra ele ficar meses internado, ele ficou dez dias e o hospital dispensou de tanto que ele incomodou no hospital e ai voltou pra casa... dai ele tava com tuberculose, tomando remédio... Quando ele ficou internado eu fui até o hospital, como eu não tinha o exame que eu tinha feito lá em $₫$ tajai, fiz exame de novamente, pra eu já começar a tomar o remédio antes de qualquer coisa... mas tava um problema de greve na área da saúde lá em Stalvador e eles demoraram muito pra dar o resultado... fo foi ficando perto do natal, ai eu jấ tava há um ano em Osalvador, e eu tinha muita faxina pra fazer.. Ali uma senhora me chamou pra fazer uma faxina e aí ela deu um produto quimico pra eu usar e quando eu usei pra limpar a escada, era veneno pra cupim, e era uma quantidade muito grande, quando cu aspirei aquilo queimou o meu pulmão esquerdo... Ali provavelmente o meu sistema imunológico tava baixo e ai eu comecei a ficar doente...com febre...com isso, com aquilo, dai eu fui no médico, tomei remétios... fui melhorando... \& ele agressivo, ele infernal dentro de casa...desde que eu cheguei em Osalvador eu freqüentava dois centros espinitas, eles ajudavam muito a gente também... Ali não pude mais trabalhar, fui ficando doente, ficando doente... \&u não me levantava da cama... Dai chegou um dia que eu fálei pro meu filho mais novo pedir pro tio da namoradinha dele me levar pro hospital señũo eu ia acabar morrendo naguela cama... for bem na

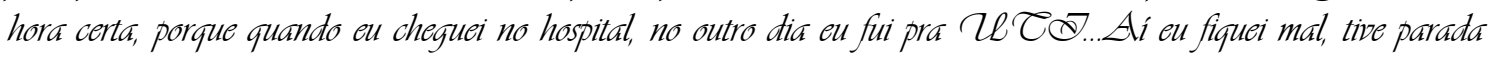
respiratónia na dia que eu cheguei já... Qsso foi bem no comecinho de janeiro de 1999... fiquei em coma três diass..fiquei dezoito dias na ZL T®... fiquei trés meses e dois dias internada... foi quando o meu filho ligou pra minha familia em Ssanta Patarina e fálou pra eles que eu tava com.... Deu o meu diagnóstico... Dai todo mundo

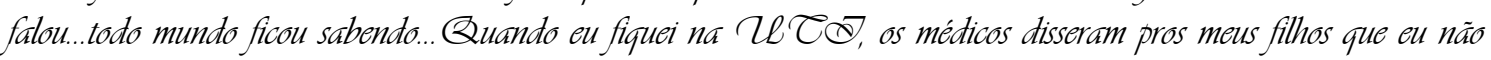
sobreviveria...que eu não tinha tinha uma chance de sobreviver... figuei mal, tudo aconteceu... \&u tive problema de respiraçấ, a minha boca ficou toda em ferida... Tudo, tudo, tudo... \& u entrei em coma num dia, acordei depois de quatro dias eu tinha emagrecido vinte quilos... \&u fiquei com cinqüenta quilos... \&u näo fălava... \&u comia praticamente igual a um bicho...tudo que eu comia era pastoso por causa das feridas na boca... \&u babava igual a um animal, que nem a saliva eu conseguia engolir... \& os médicos diziam que eu não me salvava... diziam pros meus filhos

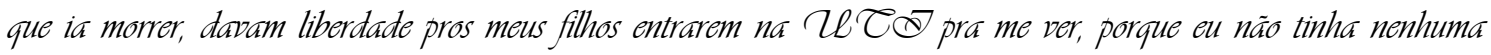
chance de sobreviver, nenhuma... \& eu fui, fui me recuperando...Assim, quando eu sai do coma que eu tinha a chance de pensar, porque quando tu ta em coma tu não pensa... Quando eu acordei do coma eu não lembrei de absolutamente nada do que tinha acontecido durante aqueles dius... Até quando eu acordei do coma, como eu sou espirita, eu pensei 
que tivesse morrido e tivesse desencarnado e tivesse em outro patamar... Dorque eu tava num lugar, quando eu acordei estava num lugar completamente diferente, a primeira reagcão que eu tive é que tivesse morta... Dai me mexi, eu tava cheia de aparelhos, dai apitou lâ, dai veio uma enfermeira e me disse: Drä́o morresse ainda näol... Dai eu senti que

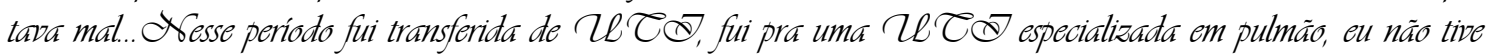
tuberculose porque tomei remédio pra näo ter...pra me prevenir, porque o meu pulmãa ficou muito sensivel... \& u passei

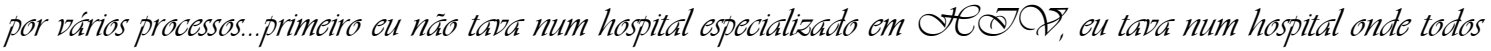
cuidavam dos pulmôes. Ali eu sofri preconceito não por parte das pessoas internadas, mas dos próprios médicos e

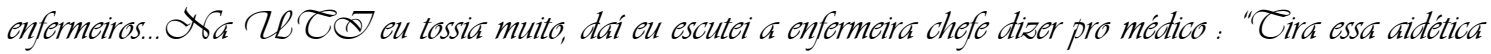

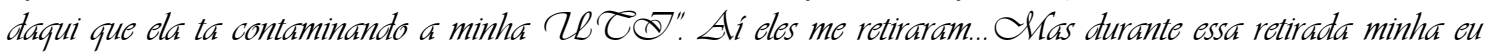
quase ia morrendo... OSisso o diretor do hospital veio me socorrer... @sso numa cidade grande, sozinha, sem ninguém... () meu filho mais velho trabalhava, o meu filho mais novo tinha menos de dezoito anos e não potia me acompanhar... \& o meu marido tava em casa doente, mal... Depois, logo em seguida ele foi internado também, ele ficou no segundo andar e eu fiquei no quinto... \& u sobrevivi, ele morreu... foi horrivel, mas eu sobrevivi... Utma coisa boa que eu tenho, é que eu sempre acho soluçöes pras coisas dificeis que eu passo... \&u sempre consigo sair da lama... \&u sempre acho uma saida... ou trabalhando de doméstica, ou varrendo as coisas, ou fazendo artesanato, ou limpando o quintal dos outros, ou trabalhando por conta, ou fazendo concurso, estudando, eu sempre consigo sair da situaçã̃o dificil com o trabalho. QEu tive vários homens na minha vida, mas nunca me prostitui, nãao precisei usar desse artificio pra sobreviver...e sempre sobrevivi do meu trabalho...mesmo sendo casada eu sempre comi o que eu trabalhei, sempre trabaithei e gosto de trabalhar... Acho que uma das coisas que engrandece a gente, far bem pra gente é trabalhar... Pomecei tudo novamente. Espero que eu näo tenha que comecar do zero novamente, mas se tiver vai ser

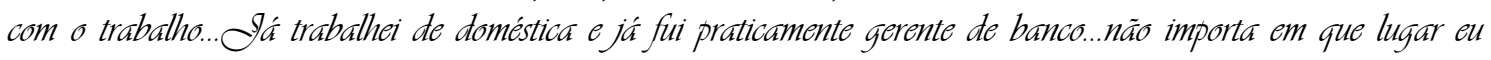
sobrevivi,, sempre consigo ressurgir das cinzas...

$$
* * *
$$

Esses extensos relatos de Domitila e Fênix apresentados propositalmente em forma de narrativas quase que cronológicas de suas trajetórias expõem cada um a sua maneira vivências urbanas, cujos itinerários nos remetem a pensar primeiro $\boldsymbol{a}$ “memória da cotidianidade”, aqui, - seja na ida de Fênix para Salvador na busca de emprego, ou na sua promoção de trabalho para São Paulo como uma forma de ascensão social, moral e econômica e ao mesmo tempo desilusão pela "cidade de muros"(Caldeira, 2000) por conta de um grave assalto ou, com a ida para Campo Grande por Domitila em busca de sua família, sua esperança depositada no Rio de Janeiro em busca de aventura (Simmel,1998) e ascenção, entre outros; e segundo a "memória coletiva" apontada por meio dos relatos das narradoras, representados aqui por uma Campo Grande com "ar" bucólico e ao mesmo tempo indecente com os menos favorecidos social e economicamente; uma Rio de Janeiro seletiva e preconceituosa etnicamente; uma São Paulo rica em oportunidades de ascensão econômica e social, 
mas rigorosa e impiedosa na manutenção desses, e ainda uma São Paulo racista e insegura ou uma Salvador festiva, acolhedora e promiscuamente seletiva.

Enfim, penso que se "memória da cotidianidade e memória coletiva" são dois “eixos necessários de participação do antropólogo na formulação da 'aura estética de uma cidade como fenômeno que se propaga com regularidade e uniformidade em face das rupturas vividas por seus habitantes" (Rocha \& Eckert, 2000:99), as extensas, mas contundentes narrativas de Domitila e Fênix fornecem-nos elementos da "teatralidade" de suas vidas cotidianas seja na cidade de São Paulo, Salvador, Campo Grande, Rio de Janeiro, entre outras, bastante significativos para nossa "análise e interpretação do fenômeno urbano e uma das dimensões de entendimento da vida social" (Rocha \& Eckert, 2000:99) dessas narradoras moradoras.

\section{Referências:}

BACHELARD, G. A dialética da duração. São Paulo: Editora Ática, 1988.

BENJAMIN, W. Illuminations. ARENDT, H. (org.). New York: Schocken Books, 1969.

CALDEIRA, T. Cidade de muros. Crime, segregação e cidadania em São Paulo. São Paulo: editora 34, edusp, 2000.

CANEVACCI, M. M. A cidade polifônica. São Paulo: Studio Nobel, 1997.

CARDDOSO DE OLIVEIRA, R. Sobre o pensamento antropológico. Rio de Janeiro:1997.

CLIFFORD, J. A Experiência etnográfica. Antropologia e literatura no século $X X$.James Clifford; organizado por José Reginaldo Santos Gonçalves. 2. ed. Rio de Janeiro: Editora UFRJ,2002.

DELEUZE, G. e FELIX, Guattari. Mil Platôs. Capitalismo e esquizofrenia. Vol.1. Tradução Aurélio G. Neto e Célia P. Costa. São Paulo: editora 34, 2004.

DURAND, G. As Estruturas Antropológicas do Imaginário. Introdução à arquetipologia geral. São Paulo: Martins Fontes, 2002.

ECKERT, C. e ROCHA, A. L. C. da. O tempo e a cidade. Porto Alegre: Editora da UFRGS, 2005.

ECKERT, C. e ROCHA, A. L. C. "Imagens do tempo nos meandros da memória: por uma etnografia da duração". Porto Alegre: banco de imagens e efeitos Visuais, PPGAS/ UFRGS,2000.15 f. (Iluminuras; n.4).

ECKERT, C. e ROCHA, A. L. C. "A memória como espaço fantástico". Porto Alegre: banco de imagens e efeitos Visuais, PPGAS/UFRGS,2000. 16 f. (Iluminuras; n.2).

ECKERT, C. e ROCHA, A. L. C "remissas para o estudo da memória coletiva no mundo urbano contemporâneo sob a ótica dos itinerários urbanos e suas formas de sociabilidade". Porto Alegre: banco de imagens e efeitos Visuais, PPGAS/UFRGS,2000. 20f. (Iluminuras; n.15).

ECKERT, C. e ROCHA, A. L. C “Jogos de Memória”. Porto Alegre: banco de imagens e efeitos Visuais, PPGAS/UFRGS,2000. . (Iluminuras; n.12).

LÉVI-STRAUSS, C. Tristes trópicos. São Paulo: Companhia das Letras, 2002. 
MORIN, E. Ensaios de Complexidade. Porto Alegre, 1999

RICOEUR, P.A Memória, a história, o esquecimento.Campinas/SP: Editora da Unicamp, 2007.

ROCHA, A.L.C. "Antropologia das formas sensíveis: entre o visível e o invisível, a floração de símbolos". In: Horizontes Antropológicos, Antropologia Visual, Ano 1, vol.2.,1995.

SIMMEL, Georg. "Estética e sociologia". (tradução Maldonado, Simone Carneiro). Política e Trabalho/ 14. Set. PPGS/UFPB,1998.

SIMMEL, Georg.. "Sobre a individualidade e as formas sociais". 1 ed.. Quilmes. Universidad Nacional de Quilmes.,2002.

VELHO, Gilberto \& Alvito, Marcos ( org. ). Cidadania e Violência. $2^{\text {a }}$ Edição. Rio de janeiro: Editora UFRJ: Editora FGV, 2000.

VELHO, Gilberto. Individualismo e cultura: notas para uma antropologia da sociedade contemporânea. Rio de janeiro: Zahar, 1981.

VELHO, Gilberto. Projeto e metamorfose. Rio de Janeiro: Jorge Zahar, 1994.

WAIZBORT, Leopoldo As aventuras de Georg Simmel. São Paulo: editora 34.,2000.

ZALUAR,A.. A máquina e a Revolta. São Paulo: Brasiliense, 1985.

ZALUAR,A.."Cidadania , Vitimização e Políticas Públicas”; Internacional Seminar "Violence, Social Control ande Public Order", Núcleo de estudos da Violência, USP, São Paulo; em Internacional Journal of Urban and Reginal Research, vol. 17, n. 1 , march, 1993

ZALUAR,A ; ALVITO, M.Um século de favela. $3^{\text {a }}$ Edição, Rio de Janeiro, Editora FGV, 2003. 